\title{
ABL gene kinase domain mutation scanning by denaturing high performance liquid chromatography sequencing method
}

\author{
Denatüre edici yüksek performanslı likit kromotografi yöntemi ile \\ ABL geni kinaz bölgesi mutasyonlarının taranması
}

\author{
Yücel Erbilgin ${ }^{1}$, Suzin Çatal1 ${ }^{1}$ Ahmet Emre Eşkazan², Özden Hatırnaz \\ Teoman Soysal ${ }^{2}$, Uğur Özbek ${ }^{1}$ \\ ${ }^{1}$ Department of Genetics, Institute of Experimental Medicine, Istanbul University, Istanbul, Turkey \\ ${ }^{2}$ Adult Hematology Division, Cerrahpaşa Faculty of Medicine, İstanbul University, İstanbul, Turkey
}

\begin{abstract}
Objective: Despite the efficacy of the BCR-ABL tyrosine kinase inhibitor imatinib, the development of resistance against imatinib has been observed. The most important mechanisms known to cause resistance are point mutations in the ABL tyrosine kinase and the ATP domain. This study describes the use of denaturing high performance liquid chromatography (dHPLC) as a method to screen for mutations of the $\mathrm{ABL}$ gene.

Material and Methods: We used the dHPLC based assay for the screening of ABL point mutations. Forty chronic myeloid leukemia (CML) patients who showed resistance to imatinib were screened in parallel by dHPLC and direct sequencing.

Results: Nine of the 40 patients (23\%) had mutations.

Conclusion: dHPLC can be a useful method for pre-screening. Analyzing the mutations and monitoring (high-risk) patients can improve their prognosis and survival rate. dHPLC can potentially become a valuable tool for regular testing of patients in the future. (Turk J Hematol 2011; 28: 97-102)

Key words: Chronic myeloid leukemia, imatinib resistance, mutation, dHPLC

Received: February 12, 2010

Accepted: August 19, 2010

\section{Özet}

Amaç: Bir BCR-ABL tirozin kinaz inhibitörü olan imatinib'in etkinliğine karşın bazı hastalarda ilaca karşı direnç gelişimi gözlenmektedir.. Direnç gelişimine neden olan en önemli mekanizma, ABL geninin tirozin kinaz ve ATP bölgelerindeki nokta mutasyonlarıdır. Bu çalışma $A B L$ gen mutasyonlarının taranmasında denatüre edici HPLC (dHPLC) yönteminin yerini ve önemini açıklama amacıyla yapılmıştır.

Yöntemler ve Gereçler: ABL nokta mutasyonları, dHPLC kullanılarak taranmıştır. Imatinib direnci gösteren $40 \mathrm{KML}$ hastası DHPLC ve paralelinde doğrudan sekanslama ile incelenmiştir.

Bulgular: Kırk hastanın dokuzunda (\%23) mutasyon saptandı.
\end{abstract}




\begin{abstract}
Sonuç: dHPLC yararlı bir ön tarama yöntemi olabilir. Mutasyon analizleri ile yüksek riskli hastaların monitörizasyonu prognozu iyileştirebilir ve să̆ kalım oranını arttırabilir. Gelecekte dHPLC bu hastaların düzenli aralıklarla izleminde değerli bir araç olarak kullanılabilir.

(Turk J Hematol 2011; 28: 97-102)
\end{abstract}

Anahtar kelimeler: Kronik miyeloid lösemi, Imatinib direnci, mutasyon, dHPLC

Geliş tarihi: 12 Şubat 2010

Kabul tarihi: 19 Ağustos 2010

\section{Introduction}

Chronic myeloid leukemia (CML) is a proliferative stem cell disorder that affects patients in all age groups [1,2]. The clinical course of CML is characteristically triphasic, starting with a chronic phase (CP) of variable duration, followed by progression to an accelerated phase (AP) and finally resulting in blast crises (BC) [3-5]. CML is the first discovered human cancer associated with a consistent chromosomal abnormality-the chimeric $B C R / A B L$ gene, known as Philadelphia (Ph) chromosome [6,7]. This translocation causes an unregulated tyrosine kinase activity and has a pivotal role in CML pathogenesis. Approximately $95 \%$ of CML patients have $B C R / A B L$ rearrangement, indicating it is a suitable drug target for anticancer therapy $[8,9]$.

Imatinib mesylate (IM) is a potent and selective inhibitor of BCR-ABL tyrosine kinase, the first rationally designed, molecularly targeted therapy for a human malignancy [10-13]. Despite the high rates of hematologic and cytogenetic responses, some patients show IM resistance in both phases. Resistance to IM can be defined as the lack of complete hematological response in patients with $\mathrm{CP}$ disease or as lack of return to $\mathrm{CP}$ for patients in an $\mathrm{AP}$ or $\mathrm{BC}[14,15]$.

Several underlying mechanisms for IM resistance have been studied in CML patients and cell lines. Drug resistance has mostly arisen as a result of point mutations in the $B C R-A B L$ gene that reduce drug binding within the kinase domain or due to overexpression of BCR-ABL protein [15-18]. In clonal selection, $B C R-A B L$ mutated cells have a higher survival rate due to the selective pressure of imatinib therapy. A number of mutations have been well characterized in terms of their ability and the degree to which they induce resistance [17,19-22]. Today, second-generation tyrosine kinase inhibitors (TKIs) have become available (Dasatinib, Sprycel, Bristol-Myers Squibb; Nilotinib, Tasigna, Novartis Pharma) in the market [23-25].
In clinical practice, cytogenetic monitoring (as fluorescence in situ hybridization-FISH) and reverse transcription quantitative polymerase chain reaction (RQ-PCR) have become gold standard monitoring assays, and they are becoming increasingly standardized between laboratories [26-28]. Furthermore, CML treatment should be monitored correctly and cABL kinase domain mutations should be investigated. However, there are no widely accepted guidelines at present for the screening of $\mathrm{Ph}+\mathrm{CML}$ mutations [18,26,28]. Therefore, we report here the use of denaturing high performance liquid chromatography (dHPLC) and sequencing methods to screen for mutations in the nucleotide binding loop (P-loop), the catalytic domain and the activation loop of the $A B L$ gene.

\section{Materials and Methods}

\section{Patients}

Peripheral blood (PB) samples were obtained from 40 imatinib-resistant or -intolerant CML patients, who were diagnosed between 1999 and 2007 in the Adult Hematology Division of Istanbul Medical Faculty, Istanbul. All patients showed resistance to $400 \mathrm{mg} /$ day imatinib. Imatinib resistance was defined as inadequate initial response or loss of hematologic or cytogenetic response at any time during the treatment. All of the patient's materials were stored at $-80^{\circ} \mathrm{C}$ after homogenization in RLT buffer (Qiagen, GmbH, Germany). One PB sample from a CML patient known to be wild-type for $A B L$ mutations was used as a negative control. We obtained written informed consents from all patients

\section{RNA isolation and cDNA synthesis}

Total RNA was isolated by Qiagen RNeasy Protect kit (Qiagen, GnbH, Germany). RNA samples were treated with DNAse $(1 \mathrm{U} / \mu \mathrm{g})$ for the possible DNA contaminations during isolation. $1 \mu \mathrm{g}$ of total RNA was used for cDNA synthesis by using random hex- 
amers and MMLV reverse transcriptase according to the protocol of the manufacturer (Fermentase).

\section{Nested PCR and experimental design of dHPLC analysis}

Mutation detection in the nucleotide binding loop (P-loop), the catalytic domain and the activation loop of the $A B L$ gene was performed via PCR-based dHPLC using a WAVE DNA fragment analysis system (Transgenomic). We used a nested-PCR approach for amplification of the ABL kinase domain with primers and PCR conditions described before [18]. First PCR was performed with $2 \mu \mathrm{l}$ of cDNA and exons 12,13 on BCR mRNA and exon 8 on ABL mRNA were amplified. The ABL kinase domain was divided into two partially overlapping fragments; codons 206- 335 (fragment B) and codons 262- 421 (fragment C) were amplified separately. This procedure ensures that the wild-type ABL transcript is not analyzed [18].

Using Wavemaker software (Transgenomic), we selected optimal temperatures for the two ABL mRNA fragments. Annealed PCR fragments (8-15 $\mu \mathrm{l}$ per sample) were injected into the DNASep HT cartridge for analysis at the following selected temperatures: Fragment $\mathrm{B}$ at $61.3,62.3^{\circ} \mathrm{C}$ and fragment $\mathrm{C}$ at $60.2,61.1^{\circ} \mathrm{C}$.

Products were eluted at a constant flow rate of $1.5 \mathrm{ml} / \mathrm{min}$ with a linear acetonitrile gradient determined by Navigator software (Transgenomic) based on the size and GC-content of the amplicon. The gradient was formed by combining buffer A $(0.1 \mathrm{M}$ TEAA) (Transgenomic) and Buffer B (0.1M TEAA with $25 \%$ acetonitrile) (Transgenomic). The elution profiles of DNA fragments, monitored by the system's UV detector, were used to produce chromatographs. A wild-type sample was used as a negative control. Less stable heteroduplexes denature earlier than homoduplexes and, thus, appear first in elution profiles. Patients' chromatograms were compared with the wild-type profile, and samples with different characters (eluted before normal homoduplexes) were scored as positive. In addition to positive scored samples, crude PCR products from patients scored as "negative" were also directly sequenced to exclude the presence of undetected genetic variations. Sequences were compared with the wild-type sequence and analyzed using CLC combined Workbench software (V.3.6.1, Denmark).

\section{Results}

In this paper, we set up a straightforward, highthroughput dHPLC-based assay to screen for the presence of mutations in the catalytic domain of ABL tyrosine kinase of 40 Turkish CML patients with imatinib resistance. Nine of 40 patients (23\%) had point mutations, and mutation characteristics of the patients are shown in Table 1. Four mutations (M244V, G250E, Y253H, V304I) fell within the nucleotide-binding loop (P-loop) that was involved in ATP binding. We observed that two mutations (F359C, K357R) affected the catalytic domain and two mutations (T315I, F317L) were located in imatinib-binding residues. We identified two novel amino acid substitutions (V304I, K357R) affecting codons known as the hotspot region. Representative dHPLC chromatograms for fragments $\mathrm{B}$ and $\mathrm{C}$ are illustrated in Figure 1.

\section{Discussion}

The basis of current therapy for CML in the CP includes the three TKIs - imatinib, dasatinib and nilotinib - and allogeneic hematopoietic stem cell transplantation (allo-HSCT). The treatment algorithm appears simple and easy to follow. Imatinib is the recommended first-line treatment for newly diagnosed CP CML at an initial standard dose of $400 \mathrm{mg}$ daily, dasatinib or nilotinib is second line, and alloHSCT is for instances of failure of drug therapy. A partial guide to the choice of second-generation TKIs may be provided by the detection of some mutations $[2,5,15,17-19,21,26]$. Therefore, it is recommended that molecular laboratories incorporate this analysis

Table 1. BCR-ABL mutation characteristics of patients

\begin{tabular}{lccc}
\hline Patient & Base change & Amino acid substitution & Status \\
\hline ABL11 & ACT $>$ ATT & T315I & $R$ \\
ABL13 & TTC $>$ TTG & F317L & R \\
ABL15 & GGG $>$ GAG, TTC $>$ TGC & G250E, F359C & R \\
ABL16 & ATG $>$ GTG & M244V & R \\
ABL17 & TAC $>$ CAC & Y253H & R \\
ABL20 & ACT $>$ ATT & T315I & R \\
ABL25 & TTC $>$ TTG & F317L & R \\
ABL29 & GTC $>$ ATC & V304I & N \\
ABL34 & TTC $>$ TTG, AAA $>$ AGA & F317L and K357R & R, N \\
\hline
\end{tabular}

R: Previously reported; N: Previously undescribed 
into their testing procedures [18,26]. In this paper, we used direct sequencing and dHPLC. Direct sequencing is the most widespread method applied in the routine monitoring of patients. However, its sensitivity is low (20\%), and it may cause false-negative results. Therefore, we used dHPLC technique, which has a sensitivity of $1-5 \%$ in mutation detection, in addition to the sequencing [29-31].

We found $B C R-A B L$ mutations localized in the P-loop, in the catalytic domain. The P-loop normally acts as nucleotide-binding loop for the phosphate groups of ATP, and its mutations are the most serious and common mutations. The catalytic domain is involved in the catalytic process [14-16,32-35]. In our study group, we detected (M244V, G250E, Y253H, V304I) substitutions in P-loop domain, (K357R, F359C) mutations in catalytic domain and (T315I, F317L) mutations in the imatinib-binding site. M244V, G250E, F317L, and F359C mutations might be overcome by dose-escalation [5,14,18,26,36]. However, Y253H mutation confers a highly resistant phenotype, suggesting withdrawal of imatinib in favor of alternative therapeutic strategies [18,26]. Two patients showed T315I mutation, which interfered with a critical hydrogen bond that forms between the ABL kinase and imatinib. It is known to be resistant to imatinib as well as the second-generation TKIs. Other than mutations, clinical relevance of other differences between dasatinib and nilotinib is unknown [5,26,36,37].

dHPLC is a sensitive and simple way to detect low level of mutations, based on differentiation in elution profiles. The results of the dHPLC showed several heteroduplex peaks on the chromatograms of samples (Figure 1). All abnormal elution profiles were parallel to sequencing results. As a result, dHPLC seems to be a reliable method for use in the pre-screening process. Certainly, the sequencing must confirm a mutation and tell us the exact mutation type.

Mutations can occur among imatinib-resistant and -intolerant patients, and sensitive detection of the mutation status might be important for the patients who are resistant to imatinib. The European LeukemiaNET (ELN) recommends mutation analysis in occurrences of suboptimal response or failure of $400 \mathrm{mg}$ daily imatinib treatment. The suboptimal response refers to no cytogenetic response after three months of therapy, less than partial cytoge-

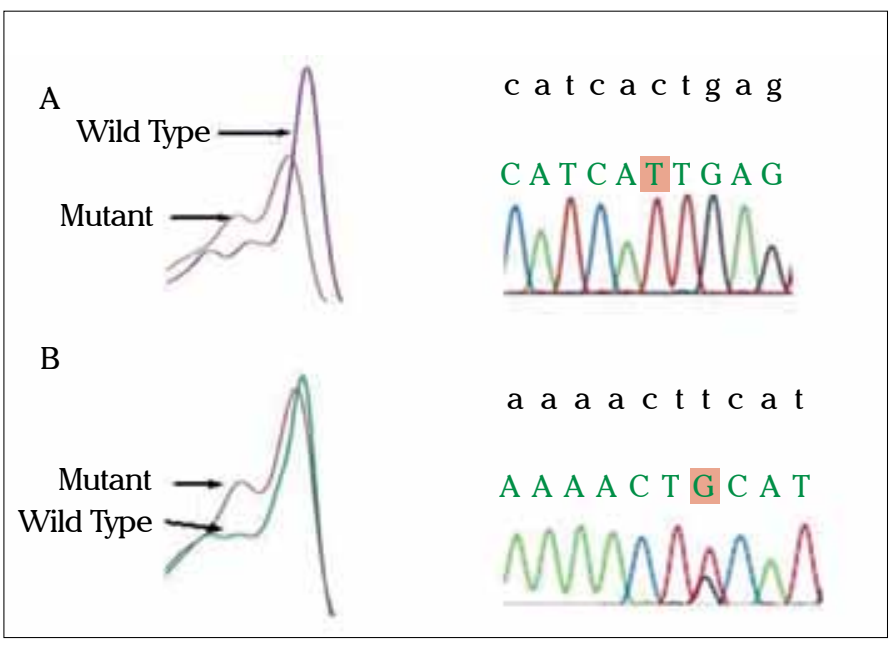

Figure 1. dHPLC chromatograms and direct sequencing of mutant DNA for fragments B and C. (A) dHPLC profiles of two representative mutants overlaid with the wild-type profiles (left panel), fragment $B$ at $61.3^{\circ} \mathrm{C}$; (right panel); ACT >ATT, T315I. (B) dHPLC profiles of two representative mutants overlaid with the wild-type profiles (left panel), fragment $\mathrm{C}$ at $60.2^{\circ} \mathrm{C}$; (right panel); TTC $>$ TGC, F359C

netic response after six months of therapy, only achieving a partial cytogenetic response at 12 months of treatment, or less than major molecular response after 18 months of treatment. Furthermore, loss of the major molecular response at any time during the treatment or detection of a mutation is so-called suboptimal response. Treatment failure refers to not achieving a complete hematological response after three months of treatment, no cytogenetic response after six months of therapy, less than a partial cytogenetic response after 12 months of treatment, or incomplete cytogenetic response after 18 months of treatment. Losing the complete hematological response or complete cytogenetic response at any time during the treatment and detection of a mutation that is poorly sensitive to imatinib or the second- generation TKIs or clonal chromosome abnormalities are also considered failure. By determining the mutational status of a patient, the right therapy option (second-generation TKIs, alloSCT, experimental drugs, etc.) can be selected for each patient [38]. dHPLC system shows higher sensitivity (95-99\%) for detecting minor clones in the mixed follow-up patient samples. Conventional direct sequencing has lower detection sensitivity to perform such analysis (about 80-90\%) [29,31]. Therefore, we suggest using dHPLC screening as a routine approach to screen ABL kinase domain mutations, which can be confirmed by sequence analyses. 


\section{Acknowledgements}

This work was funded by T.R. Prime Ministry State Planning Organization (Project no: 2005K120430).

\section{Conflict of interest statement}

The authors of this paper have no conflicts of interest, including specific financial interests, relationships, and/or affiliations relevant to the subject matter or materials included.

\section{References}

1. Rowley JD. Letter: A new consistent chromosomal abnormality in chronic myelogenous leukaemia identified by quinacrine fluorescence and Giemsa staining. Nature 1973;243:290-3. [CrossRef]

2. National Comprehensive Cancer Network (2008). Chronic myelogenous leukemia V.I.2008. NCCN Clinical Practice Guidelines in Oncology. http://www.nccn.org/ professionalsphysician_gls/PDF/cml.pdf. Accessed 19 September 2008.

3. Griffin JD, Todd RF 3rd, Ritz J, Nadler LM, Canellos GP, Rosenthal D, Gallivan M, Beveridge RP, Weinstein H, Karp D, Schlossman SF. Differentiation patterns in the blastic phase of chronic myeloid leukemia. Blood 1983;61:85-91.

4. Bettelheim P, Lutz D, Majdic O, Paietta E, Haas O, Linkesch W, Neumann E, Lechner K, Knapp W. Cell lineage heterogeneity in blast crisis of chronic myeloid leukaemia. Br J Hematol 1985;59:395-409.

5. European LeukemiaNet (2008) Management of chronic myeloid leukemia (CML): recommendations from the European LeukemiaNet (ELN). http://www.leukemia-net.org/content/leukemias/cml/standards_sops/ recommendations/. Accessed 2 Sept 2008.

6. Bartram CR, de Klein A, Hagemeijer A, van Agthoven T, Geurts van Kessel A, Bootsma D, Grosveld G, FergusonSmith MA, Davies T, Stone M, et al. Translocation of c-abl oncogene correlates with the presence of a Philadelphia chromosome in chronic myelocytic leukaemia. Nature 1983;306277-80. [CrossRef]

7. Groffen J, Stephenson JR, Heisterkamp N, de Klein A, Bartram CR, Grosveld G. Philadelphia chromosomal breakpoints are clustered within a limited region, bcr, on chromosome 22. Cell 1984;36:93-9.

8. Melo JV. The diversity of BCR-ABL fusion proteins and their relationship to leukemia phenotype. Blood 1996;88:2375-84.

9. Deininger MW, Goldman JM, Melo JV. The molecular biology of chronic myeloid leukemia. Blood 2000;96:3343-56.

10. Kantarjian H, Sawyers C, Hochhaus A, et al. Hematologic and cytogenetic responses to imatinib mesylate in chronic myelogenous leukemia. N Engl J Med 2002;346:645-52. [CrossRef]

11. Kantarjian H, Sawyers C, Hochhaus A, Guilhot F, Schiffer C, Gambacorti-Passerini C, Niederwieser D, Resta D, Capdeville R, Zoellner U, Talpaz M, Druker B,
Goldman J, O'Brien SG, Russell N, Fischer T, Ottmann O, Cony-Makhoul P, Facon T, Stone R, Miller C, Tallman M, Brown R, Schuster M, Loughran T, Gratwohl A, Mandelli F, Saglio G, Lazzarino M, Russo D, Baccarani M, Morra E; International STI571 CML Study Group. Efficacy and safety of a specific inhibitor of the BCRABL tyrosine kinase in chronic myeloid leukemia. N Engl J Med 2001;344:1031-7.

12. Ottmann OG, Druker BJ, Sawyers CL, Goldman JM, Reiffers J, Silver RT, Tura S, Fischer T, Deininger MW, Schiffer CA, Baccarani M, Gratwohl A, Hochhaus A, Hoelzer D, Fernandes-Reese S, Gathmann I, Capdeville $\mathrm{R}$, O'Brien SG. A phase 2 study of imatinib in patients with relapsed or refractory Philadelphia chromosome-positive acute lymphoid leukemias. Blood 2002;100:1965-71.

13. Rosti G, Martinelli G, Bassi S, Amabile M, Trabacchi E, Giannini B, Cilloni D, Izzo B, De Vivo A, Testoni N, Cambrin GR, Bonifazi F, Soverini S, Luatti S, Gottardi E, Alberti D, Pane F, Salvatore F, Saglio G, Baccarani M; Study Committee, Italian Cooperative Study Group for Chronic Myeloid Leukemia; Writing Committee, Italian Cooperative Study Group for Chronic Myeloid Leukemia. Molecular response to imatinib in late chronic-phase chronic myeloid leukemia. Blood 2004;103:2284-90.

14. Shah NP, Nicoll JM, Nagar B, Gorre ME, Paquette RL, Kuriyan J, Sawyers CL. Multiple BCR-ABL kinase domain mutations confer polyclonal resistance to the tyrosine kinase inhibitor imatinib (STI571) in chronic phase and blast crisis chronic myeloid leukemia. Cancer Cell 2002;2:117-25. [CrossRef]

15. Gorre ME, Mohammed M, Ellwood K, Hsu N, Paquette R, Rao PN, Sawyers CL. Clinical resistance to STI-571 cancer therapy caused by BCR-ABL gene mutation or amplification. Science 2001;293:876-80. [CrossRef]

16. Hochhaus A, Kreil S, Corbin AS, La Rosée P, Müller MC, Lahaye T, Hanfstein B, Schoch C, Cross NC, Berger U, Gschaidmeier H, Druker BJ, Hehlmann R. Molecular and chromosomal mechanisms of resistance to imatinib (STI571) therapy. Leukemia 2002;16:2190-6. [CrossRef]

17. Branford S, Rudzki Z, Walsh S, Parkinson I, Grigg A, Szer J, Taylor K, Herrmann R, Seymour JF, Arthur C, Joske D, Lynch K, Hughes T. Detection of BCR-ABL mutations in patients with CML treated with imatinib is virtually always accompanied by clinical resistance, and mutations in the ATP phosphate-binding loop (P-loop) are associated with a poor prognosis. Blood 2003;102:276-83.

18. Soverini S, Martinelli G, Amabile M, Poerio A, Bianchini M, Rosti G, Pane F, Saglio G, Baccarani M; Italian Cooerative Study Group on Chronic Myeloid Leukemia; European LeukemiaNet-6th Framework Program of the European Community. Denaturing-HPLC-based assay for detection of $\mathrm{ABL}$ mutations in chronic myeloid leukemia patients resistant to Imatinib. Clin Chem 2004;50:1205-13.

19. Soverini S, Martinelli G, Rosti G, Bassi S, Amabile M, Poerio A, Giannini B, Trabacchi E, Castagnetti F, Testoni $\mathrm{N}$, Luatti S, de Vivo A, Cilloni D, Izzo B, Fava M, Abruzzese E, Alberti D, Pane F, Saglio G, Baccarani M. 
ABL mutations in late chronic phase chronic myeloid leukemia patients with up-front cytogenetic resistance to imatinib are associated with a greater likelihood of progression to blast crisis and shorter survival: a study by the GIMEMA Working Party on Chronic Myeloid Leukemia. J Clin Oncol 2005;23:4100-9.

20. Willis SG, Lange T, Demehri S, Otto S, Crossman L, Niederwieser D, Stoffregen EP, McWeeney S, Kovacs I, Park B, Druker BJ, Deininger MW. High-sensitivity detection of BCR-ABL kinase domain mutations in imatinib-naive patients: correlation with clonal cytogenetic evolution but not response to therapy. Blood 2005; 106:2128-37.

21. Kang HY, Hwang JY, Kim SH, Goh HG, Kim M, Kim DW. Comparison of allele specific oligonucleotide-polymerase chain reaction and direct sequencing for high throughput screening of ABL kinase domain mutations in chronic myeloid leukemia resistant to imatinib. Haematologica 2006;91:659-62.

22. Melo JV, Barnes DJ. Chronic myeloid leukaemia as a model of disease evolution in human cancer. Nat Rev Cancer 2007;7:441-53.

23. Weisberg E, Manley PW, Breitenstein W, Brüggen J, Cowan-Jacob SW, Ray A, Huntly B, Fabbro D, Fendrich G, Hall-Meyers E, Kung AL, Mestan J, Daley GQ, Callahan L, Catley L, Cavazza C, Azam M, Neuberg D, Wright RD, Gilliland DG, Griffin JD. Characterization of AMN107, a selective inhibitor of native and mutant BcrAbl. Cancer Cell 2005;7:129-41. [CrossRef]

24. Lombardo LJ, Lee FY, Chen P, Norris D, Barrish JC, Behnia K, Castaneda S, Cornelius LA, Das J, Doweyko AM, Fairchild C, Hunt JT, Inigo I, Johnston K, Kamath A, Kan D, Klei H, Marathe P, Pang S, Peterson R, Pitt S, Schieven GL, Schmidt RJ, Tokarski J, Wen ML, Wityak $\mathrm{J}$, Borzilleri RM. Discovery of N-(2-chloro-6-methylphenyl)-2-(6-(4-(2-hydroxyethyl)- piperazin-1-yl)-2methylpyrimidin-4- ylamino)thiazole-5-carboxamide (BMS-354825), a dual Src/Abl kinase inhibitor with potent antitumor activity in preclinical assays. J Med Chem 2004;47:6658-61.

25. Garg RJ, Kantarjian H, O'Brien S, Quintás-Cardama A, Faderl S, Estrov Z, Cortes J. The use of nilotinib or dasatinib after failure to two prior tyrosine kinase inhibitors (TKI): long-term follow-up. Blood 2009;114:4361-8. [CrossRef]

26. Baccarani M, Pane F, Saglio G. Monitoring treatment of chronic myeloid leukemia. Haematologica 2008;93:161-9.

27. Baccarani M, Rosti G, Castagnetti F, Haznedaroglu I, Porkka K, Abruzzese E, Alimena G, Ehrencrona H, Hjorth-Hansen H, Kairisto V, Levato L, Martinelli G, Nagler A, Lanng Nielsen J, Ozbek U, Palandri F, Palmieri F, Pane F, Rege-Cambrin G, Russo D, Specchia G, Testoni N, Weiss-Bjerrum O, Saglio G, Simonsson B. Comparison of imatinib $400 \mathrm{mg}$ and $800 \mathrm{mg}$ daily in the front-line treatment of high-risk, Philadelphia-positive chronic myeloid leukemia: a European LeukemiaNet Study. Blood 2009;113:4497-504. [CrossRef]

28. Martinelli G, Iacobucci I, Soverini S, Cilloni D, Saglio G, Pane F, Baccarani M. Monitoring minimal residual disease and controlling drug resistance in chronic myeloid leukaemia patients in treatment with imatinib as a guide to clinical management. Hematol Oncol 2006;24:196-204. [CrossRef]

29. Emmerson P, Maynard J, Jones S, Butler R, Sampson JR, Cheadle JP. Characterizing mutations in samples with low-level mosaicism by collection and analysis of DHPLC fractionated heteroduplexes. Hum Mutat 2003;21:112-5. [CrossRef]

30. Antonarakis ES, Sampson JR, Cheadle JP. Temperature modulation of DHPLC analysis for detection of coexisting constitutional and mosaic sequence variants in TSC2. J Biochem Biophys Methods 2002;51:161-4. [CrossRef]

31. Wolford JK, Blunt D, Ballecer C, Prochazka M. Highthroughput SNP detection by using DNA pooling and denaturing high performance liquid chromatography (DHPLC). Hum Genet 2000;107:483-7. [CrossRef]

32. Branford S, Rudzki Z, Walsh S, Grigg A, Arthur C, Taylor K, Herrmann R, Lynch KP, Hughes TP. High frequency of point mutations clustered within the adenosine triphosphate-binding region of $\mathrm{BCR} / \mathrm{ABL}$ in patients with chronic myeloid leukemia or Ph-positive acute lymphoblastic leukemia who develop imatinib (STI571) resistance. Blood 2002;99:3472-5. [CrossRef]

33. Roumiantsev S, Shah NP, Gorre ME, Nicoll J, Brasher BB, Sawyers CL, Van Etten RA. Clinical resistance to the kinase inhibitor STI-571 in chronic myeloid leukemia by mutation of Tyr-253 in the Abl kinase domain P-loop. Proc Natl Acad Sci U S A 2002;99:10700-5. [CrossRef]

34. Hofmann WK, Jones LC, Lemp NA, de Vos S, Gschaidmeier H, Hoelzer D, Ottmann OG, Koeffler HP. $\mathrm{Ph}(+)$ acute lymphoblastic leukemia resistant to the tyrosine kinase inhibitor STI571 has a unique BCR-ABL gene mutation. Blood 2002;99:1860-2. [CrossRef]

35. Roche-Lestienne C, Soenen-Cornu V, Grardel-Duflos N, Laï JL, Philippe N, Facon T, Fenaux P, Preudhomme C. Several types of mutations of the Abl gene can be found in chronic myeloid leukemia patients resistant to STI571, and they can pre-exist to the onset of treatment. Blood 2002;100:1014-8. [CrossRef]

36. Jabbour E, Kantarjian H, Jones D, Breeden M, GarciaManero G, O'Brien S, Ravandi F, Borthakur G, Cortes J. Characteristics and outcomes of patients with chronic myeloid leukemia and T315I mutation following failure of imatinib mesylate therapy. Blood 2008;112:53-5. [CrossRef]

37. Soverini S, Colarossi S, Gnani A, Castagnetti F, Rosti G, Bosi C, Paolini S, Rondoni M, Piccaluga PP, Palandri F, Giannoulia P, Marzocchi G, Luatti S, Testoni N, lacobucci I, Cilloni D, Saglio G, Baccarani M, Martinelli G. Resistance to dasatinib in Philadelphia-positive leukemia patients and the presence or the selection of mutations at residues 315 and 317 in the BCR-ABL kinase domain. Haematologica 2007;92:401-4. [CrossRef]

38. Baccarani M, Cortes J, Pane F, Niederwieser D, Saglio G, Apperley J, Cervantes F, Deininger M, Gratwohl A, Guilhot F, Hochhaus A, Horowitz M, Hughes T, Kantarjian H, Larson R, Radich J, Simonsson B, Silver RT, Goldman J, Hehlmann R; European LeukemiaNet. Chronic myeloid leukemia: an update of concepts and management recommendations of European LeukemiaNET. J Clin Oncol 2009;35:6041-51. [CrossRef] 